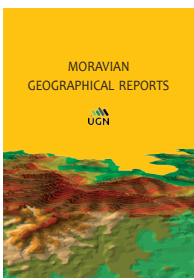

\title{
A comparison of four approaches to river landscape delineation: The case of small watercourses in the Czech Republic
}

\author{
Jiří JAKUBÍNSKÝ a *, Vladimír HERBER ${ }^{\text {b }}$, Pavel CUDLÍN ${ }^{\text {a }}$
}

\begin{abstract}
River landscapes represent key areas of great importance to human society as they perform many functions and provide valuable services. Traditionally, these areas have been perceived as geomorphological phenomena characterised by specific soil conditions, hydrological regimes and unique habitats. Due to the availability of detailed data, it is possible to perform a spatial delineation of river landscapes by interpreting these data using several different approaches. The results of these different approaches can vary considerably, since it is particularly challenging to define the river landscape along small watercourses for which the availability of suitable data is limited. The main aim of this study is to analyse the various methodological approaches that may be used to define the river landscapes of small streams, and to evaluate the efficiency of those approaches that can be applied in nature and landscape conservation. Two medium-sized catchments in the Czech Republic were selected as the study areas in order to ensure different natural conditions and degrees of anthropogenic pressure. As a result, an approach based on combining soil characteristics and topographic information is considered the most appropriate solution to delineate the river ecosystem.
\end{abstract}

Keywords: floodplain delineation; small watercourses; river landscapes; Czech Republic

Article history: Received 9 May 2019, Accepted 25 November 2019, Published 31 December 2019

\section{Introduction and theoretical background}

River landscapes represent specific ecosystems, the existence of which are directly dependent on permanent or at least periodic contact with watercourses. These areas are beneficial to society for the wide range of functions and related services they provide. Geographically defined areas are broadly in line with the spatial extent of the area traditionally referred to as a floodplain (e.g. Lewin and Manton, 1975; Décamps et al., 1988; Hugett, 2003; Nardi et al., 2006; Kilianová et al., 2017). According to Tockner and Stanford (2002), river floodplains are defined as areas of low-lying land that are subject to inundation by lateral overflow water from rivers with which they are associated. Occasionally, floodplains are also referred to as valley bottoms (Williams et al., 2000, or Lindsay, 2003) and riparian areas or buffers (McGlynn and Seibert, 2003, or Katsuyama et al., 2005).

At present, however, the term 'riparian area' usually refers only to the sites closely adjacent to the riverbed that are covered by riparian vegetation (e.g. Dufour et al., 2019). The floodplain and river landscapeareas, however, are notidentical in terms of their spatial extent. The key difference between the two terms is the fact that a river landscape is defined on the basis of its actual functions (Šterrba et al., 2008): the main assumption is the actual presence of the watercourse in the landscape. By retaining water, river landscapes can buffer the effects of heavy rainfall and in this way protect economic activities and communities further downstream from flood damage. Many former natural river landscapes, however, are under increasing pressure from urban sprawl, infrastructure developments and agriculture. In Europe, up to $90 \%$ of river landscapes have been lost during the past centuries or are no longer able to serve as functioning natural ecosystems providing flood risk reduction and habitats favouring high biodiversity (EEA, 2016).

An important factor influencing the extent of river landscapes is primarily related to the anthropogenic activities that can alter local hydrological conditions, such as roads and railways, levees, flood walls and other line structures in the floodplain, thus limiting the natural functions of the

${ }^{a}$ Global Change Research Institute of the Czech Academy of Sciences, Brno, Czech Republic (corresponding author: J. Jakubínský, e-mail: jakubinsky.j@czechglobe.cz)

${ }^{\mathrm{b}}$ Masaryk University, Faculty of Science, Department of Geography, Brno, Czech Republic 
ecosystem. Most river landscapes have been hydrologically disconnected from the riverbed by the construction of dykes and are currently often dominated by intense human use (Hein et al., 2016). According to Nilsson et al., 2005, Europe is the continent where the river landscapes are most affected by such kinds of human activities. Rinaldi et al. (2013) also noted that the habitat conditions in the remaining active floodplain areas have often been altered substantially by human impacts, such as river training, river damming, floodplain disconnection, aggradation, pollution by fertilisers and chemical contaminants, the introduction of invasive species or by intense forestry. The effects of floodplain management on the biodiversity of these unique ecosystems in several European countries were described by Schindler et al. (2016). The increasingly frequent and prolonged episodes of drought in Central Europe (e.g. Blauhut et al., 2016, or Kreibich et al., 2019) can also be perceived as one of the key variables influencing the extent of river landscapes due to decreased groundwater levels.

The basics of the "river landscape" concept first appeared in the late 1960s with the study of Leopold and Marchant (1968), who analysed the factors that formed the river landscape (then referred to as "riverscape"). Over time, the main object of study became the interactions between the different components of a river landscape, in the form of diverse patches. Energy and material flows between the patches in the river landscape environment were intensively studied through the "river continuum" concept (Vannote et al., 1980). The link between the watercourse and the surrounding area was considered the most significant and dynamic connection at that time (Amoros and Roux, 1988). The focus on solving spatial relationships in the landscape culminated with the development of the concept of habitat continuity (Ward, 1998), which received considerable attention in terrestrial landscape ecology. The contemporary understanding of a river landscape ecosystem in the AngloSaxon literature was developed much later, however, largely at the turn of the $21^{\text {st }}$ century (e.g. Fausch et al., 2002; Ward et al., 2002; Wiens, 2002). Using this concept, the river landscape is defined as an inherently heterogeneous system, formed by a river and a background that intensively communicates with the surrounding environment.

The river ecosystem delineation process has been dealt with by a number of researchers in the past (such as Malanson, 1993; Ilhardt et al., 2000 and Winter, 2001), and more recently by Carbonneau et al., 2012, Nardi et al., 2013 and Rathjens et al., 2016. The availability of appropriate and accurate underlying data, however, has always played a key role because these data are reflected in the quality of the areas delineated. The most accurate data source currently available is detailed elevation information (Deshpande, 2013) acquired with remote sensing techniques.

Considering the factors discussed above (anthropogenic influences, drought episodes, etc.), river landscapes mainly located along small watercourses could be one of the most endangered components of present landscape structures, especially in lowland and agricultural areas. These small streams, despite their usual legislative insignificance, represent a crucial element in the hydrographic network in a landscape. One reason for their significance is their considerable share of the total length of the entire river network. For example, in the Czech Republic, the total length of all small streams is approximately $91,717 \mathrm{~km}$ (i.e. almost $85 \%$ of the total length of all rivers in the Czech Republic), according to the Czech Ministry of Agriculture
(MoA, 2013). Small streams are those that are not considered to be "significant", according to a decree of the Czech Ministry of Agriculture. Small streams shape the nature of the runoff regime and they are important for the associated dynamics of water circulation in the landscape. The area that surrounds small watercourses and is characterised by the same attributes as the river landscape, may therefore be referred to as the "stream landscape". According to Šterrba et al. (2008), the area of these stream landscapes constitutes about $46 \%$ of the total area of the river landscapes in the Czech Republic, which is estimated at some $8,082 \mathrm{~km}^{2}$ based on the documents available.

The methodological framework for defining river landscapes is one of the tools to be used in real-time decisionmaking processes in nature and landscape conservation. In Europe, the protection of river landscapes (or more precisely of floodplain areas as a key element of river landscapes) is encouraged, but not explicitly required by a number of international laws and regulations, i.e. the EU Water Framework Directive (2000/60/EC), the Floods Directive (2007/60/EC), the Habitat and Birds Directives (1992/43/ EEC and 2009/147/EC), the EU 2020 Biodiversity Strategy, the Green Infrastructure initiative and the EU Climate Change Adaptation Strategy. In many cases, floodplains and river landscapes are also subject to national protection: for example, in the Czech Republic, these ecosystems are protected as a "significant landscape element" (by the Act on Nature and Landscape Protection No. 114/92 Coll.). For these reasons, it is justifiable to address the issue of defining river landscapes as an important and sensitive component of the current environment, especially with the aim of refining the identification process and increasing the efficiency of their delineation, which could help to develop better and more appropriate management of watercourses, as well as their immediate surroundings in the form of riparian habitats.

The main aim of this article is to analyse the possibilities of delimiting the river landscapes lining small watercourses (i.e. stream landscapes) by using existing background approaches. Further, we analysed the positive and negative aspects of four different approaches that are quite often used to address this issue. These approaches are:

i. the procedures based on soil cover type data (pedological approach);

ii. information about the river inundation area's spatial extent (hydrological approach);

iii. local topographical conditions (topographical approach); and

iv. the occurrence of specific habitats related to the water environment (geobotanical approach).

We paid particular attention to the accuracy of the delineation process based on resolution of the input data, and the potential application of each procedure.

\section{Case study areas}

The experimental delineation of the river landscapes was carried out on two small stream catchments, namely, the Borovský Stream basin (tributary of the Sázava river in the Bohemian-Moravian Highlands, in the central part of the Czech Republic) and the Košátecký Stream basin (tributary of the Elbe river at the town of Neratovice, approximately $30 \mathrm{~km}$ north of Prague). The exact locations of the areas of interest are shown on Figure 1. The selection of both catchments was designed to capture the widest 
range of natural conditions affecting the drainage processes in the landscape, the dynamics of river systems, and hence the extent of the area directly affected by the presence of the river. The second and equally important parameter taken into consideration when selecting the study areas was the degree and character of anthropogenic pressure to which the landscape structure is currently subjected. While the first mentioned natural conditions are the basic prerequisites for the formation of river landscapes, and thus influence the spatial pattern of these areas at the level of larger landscape structures (river basins or their parts), the anthropogenic influence primarily impacts the extent of the river landscape at the local level (the segment or reach of a watercourse). Anthropogenic activities most often limit the extent of river landscapes by significantly affecting the spatial pattern of the riverbed or the riparian zones, and by long- term interruption of the contact between the river and the surrounding landscape. The actual river landscape and its extent are the result of the interaction between the effects of human activities and the natural conditions specific to a particular place and time.

The Košátecký Stream basin, with a total area of $218.3 \mathrm{~km}^{2}$, represents in its southern half the flat and fertile area in the Elbe river floodplain, where the river landscape of this small stream is very difficult to identify without a detailed (e.g. sedimentological) survey. The northern part of the catchment has a deep sandstone valley with a naturally narrow riverbed in almost the entire length of the segments studied. The Borovský Stream catchment (with an area of $72.7 \mathrm{~km}^{2}$ ) is representative of basins with deeply incised valleys, a tectonically conditioned pattern, and with large dimensions in the lowland part.

These basins and their respective segments, are similar in character due to anthropogenic influences; however, they are different in their total extent. Our analysis focused only on the main watercourses of the two selected river basins, i.e. the Košátecký Stream, with a total length of $23.72 \mathrm{~km}$, and the Borovský Stream, with a length of $17.11 \mathrm{~km}$.

\section{Methods and data for river landscape delineation}

Based on the above-mentioned river landscape definitions, the key indicator for defining this specific ecosystem is the area where the environment is influenced by the presence of the watercourse, i.e. where the interaction between the water regime and the impacted environments take place. Several different methods can be used to locate the borderline between the terrestrial part of the river landscape and other types of landscape (see Tab. 1), but the most accurate and

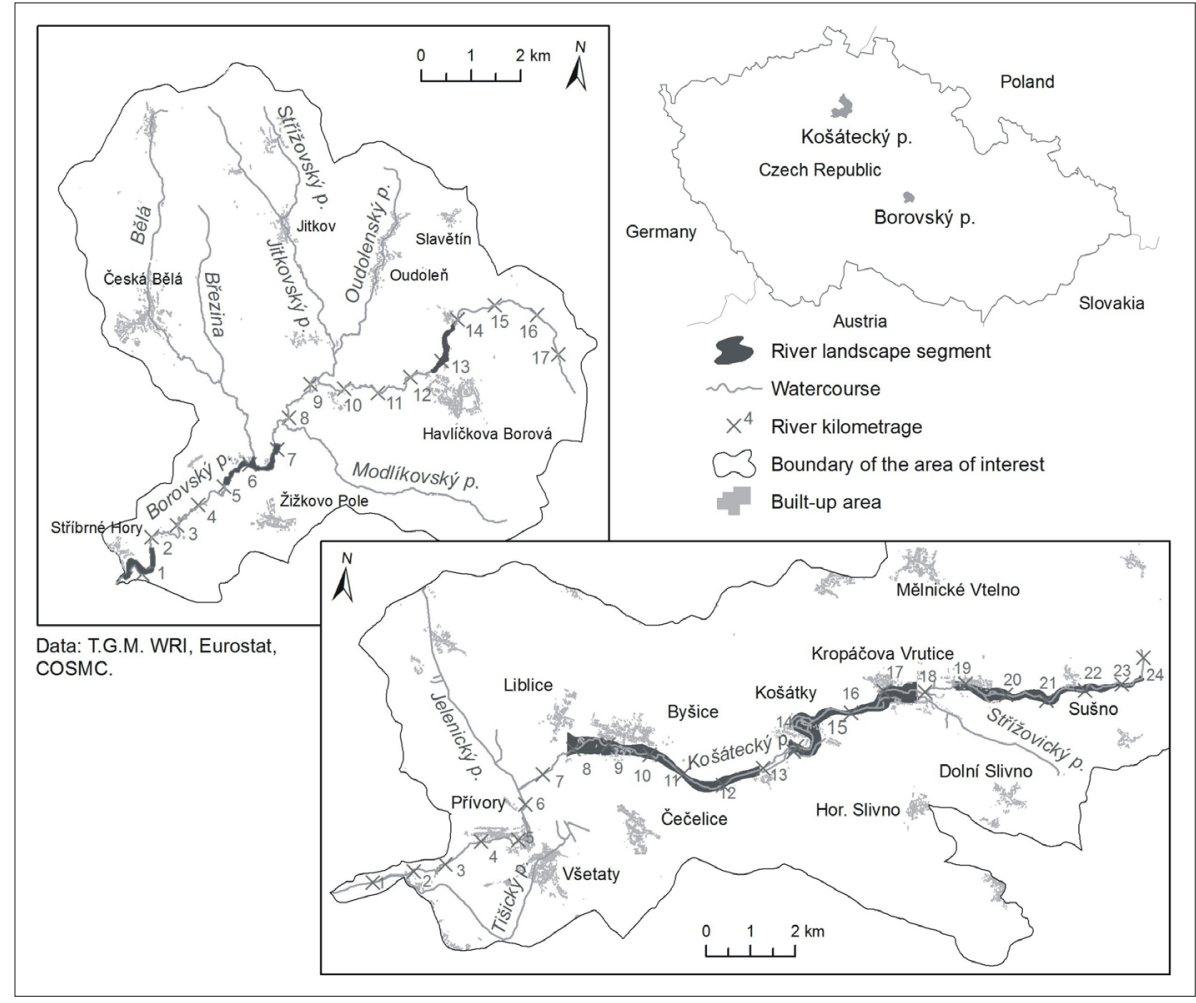

Fig. 1: Case study areas and their location within the Czech Republic Source: authors' elaboration

\begin{tabular}{ll}
\hline Methodological approach & Delineation factors (methods) taken into account \\
\hline Pedological (P) & Spatial extent of alluvial soils based on soil type terrain mapping \\
Hydrological (H) & Flood prone areas based on the methods of hydraulic and hydrological modelling \\
Topographical (T) & The flat areas of the same elevation as the riverbed edge where contact with the watercourse is ensured, \\
& based on the Fluvial Corridor (Valley Bottom) tool outputs \\
Geobotanical (G) & The areas adjacent to the watercourse where floodplain habitats occur, based on habitat mapping \\
\hline
\end{tabular}

Tab. 1: Overview of methodological approaches and the factors used for delineation of the river landscape Source: authors' conceptualisation 
reliable approach is based on an analysis of soil properties. Fluvisol ("Alluvial soil") is the most widespread soil type of river landscapes, formed by the erosion of sediments in the upland zone, and deposited in lowland areas or at sites with a flat valley floor in the transfer (piedmont) zone. Another soil type, which appears in abundance in river landscapes, is Gleysol, the formation of which is conditioned by the periodic repetition or permanent surplus of moisture in the shallow layers of the soil profile. A much less widespread soil type in the area of study is Phaeozem (Fluvi-gleyic Phaeozem according to The Food and Agriculture Organization of the United Nations (FAO, 1988)), in the form of deep semihydromorphic soils.

The spatial extent and precise location of hydromorphic soils can be determined by a detailed pedological survey. Additionally, accurate background data in the Czech Republic is provided by the system of Bonited Soil Ecological Units (BSEUs) mapping at a 1:5,000 scale. The present form of BSEUs is based on the maps of the Complex Soil Survey (CSS) realised in the former Czechoslovakia from the years 1961 to 1971 (and continuously updated to the present based on the Ministry of Agriculture Decree No. 327/1998). These maps, which are available only for agricultural land at scales of 1:5,000 or 1:10,000 depending on the particular location, represent a valuable and effective source for river landscape delineation in the vicinity of small streams. The CSS is based on a genetic and agronomic soil classification with the soil type as the base unit. The soil type is defined as the group of soils with the same stratigraphy of soil profile and with qualitatively identical geomorphological conditions (WAKPP, 2016).

We used the BSEU maps to define river landscapes within the areas of study. Since these maps only cover areas of agricultural land, however, we had to use other suitable data sources comparable to the BSEU in terms of their spatial resolution to identify the river landscapes in forested areas. The Forest Typological Maps (1:10,000), which contain information about the soil and humidity conditions of the studied sites, were considered the most suitable source of data for Central European conditions. Since these maps define forest types by combining the edificial, climatic, and phytosociological characteristics of the habitat, they were used to capture the optimal conditions for the existence of river and stream landscapes, including forest types specific to high groundwater levels and those affected by regular flooding (Chuman, 2008). Combining these two data sources, we were able to define the studied areas along a hydrographic network whose soil characteristics were formed mainly by local watercourses.

The second key approach used to define river landscapes is based on hydrological data taken from inundation maps that identify the river landscape and the floodplain on the basis of a 100-year flood area. It is theoretically possible to use other values, however: for example, Witner (1966) successfully studied the corresponding area of alluvial soils and floods with a return period of 50 years (i.e. 50year flood). According to the hydrological approach, the delineation of the selected river landscapes is based on the flood-prone area borderlines, which in the Czech Republic is available through the Digital Base of Water Management Data (DIBAVOD) provided by the T. G. Masaryk Water Research Institute (TGM WRI, 2019). The floodplain borderlines (with repeat times of 5, 20, and 100 years) are derived from the highest water level in separate watercourse profiles during a given flood episode, while the altitude is determined by a hydraulic calculation. Compared to the pedological concept of river landscapes, the hydrological approach has a major advantage in that the reaction time is much shorter, and therefore possible changes in the spatial extent of the fluvial system can be captured from the available data. These changes occur easily; most often they are related to various anthropogenic impacts on the valley floor and nearby river channels (for example, construction of railway or road embankments, flood walls, etc.). The hydrological approach thus defines the actual spatial extent of the flood-prone areas. The only significant disadvantage may be the lack of data (i.e. the flood-prone areas' delineation) in the vicinity of small watercourses; however, in these cases it is possible to obtain the needed data using separate hydrological modelling tools.

When defining the river landscape area, the procedures of classical hydrological modelling can also be replaced by specialised software focused primarily on the topographic conception. An example of such specialised software is the "FluvialCorridor" tool (the outcomes are collectively referred to as the "topographic conception" of the river landscape), which was developed at the Institute of Ecology and the Environment in France (part of the CNRS infrastructure) in cooperation with universities in Lyon, France. This procedure is based on the methodological framework for the definition and characterisation of fluvial morphological shapes, consisting of primary data in large resolution (Alber and Piégay, 2011). In principle it is a geomorphometric delineation of river landscapes based on objectively defined topographic thresholds, which is further discussed by Clubb et al. (2017). This toolkit can be used for a variety of morphometric and spatial analyses. In particular, the "Valley Bottom" function defines river or stream landscapes on the basis of a digital elevation model (namely, the $5^{\text {th }}$ generation DEM of the Czech Republic, provided by Czech office for surveying, mapping and cadastre (COSMC)). This function first provides information about the altitude of each river segment (at regular intervals), and then, based on the intersection of the relative altitude layer (user selectable) and the original DEM layer, it defines a territory that roughly corresponds to the river landscape area using a specific set of algorithms (Roux et al., 2015). Reportedly, the results of this software toolkit are only partially accurate but work well in cases of high river network density. With increasing demands for spatial resolution at the local level, their reliability decreases, and the results provided by the software need to be verified by performing field surveys.

In addition to the above-mentioned two approaches based on soil and hydrological data, the river landscape can be defined using other methods. An approach worth mentioning and one with a very long tradition in defining the river floodplain is based on combining the geological properties of the studied area with data on the geomorphological parameters of the terrain. According to Lewin (1978), floodplains (whose area roughly corresponds to the river landscape) represent sediment sinks or stores in which eroded and sorted sediments accumulate, are reworked, or indeed undergo biogenic or pedogenic processing for extended timespans. Nardi et al. (2006) consider floodplains as regions near stream channels, shaped by the accumulated effects of floods of varying magnitudes, and their associated geomorphological processes. Since this approach does not reflect the influence of current acting anthropogenic activities, and therefore differs from the definition of river landscapes, it is unsuitable for the delineation process. 
The geobotanical view of the alluvial ecosystem is based on the assumption that watercourses largely affect the vegetation cover of their surroundings. Floodplains are often characterised by a mosaic of habitats differing in age, humidity, sediment properties and productivity - and by diversity, abundance, composition and succession state of biota (Geilen et al., 2004). Since this characteristic is also indirectly included in the definition of river landscapes, it offers the possibility of applying the geobotanical approach to define the studied phenomenon. The vegetation of a floodplain and a river landscape differs from the surrounding vegetation because of its adaptation to the frequent occurrence of floods and groundwater level fluctuations. Generally, the vegetation of a floodplain forms unique plant communities that do not occur in any other landscape type and are usually arranged in relation to the axis of the riverbed in a specific location. Gurnell and Petts (2002) highlighted the strong dependence of plant communities on the hydrological and geomorphological processes in floodplains. To define this type of landscape, the geobotanical and "landscape-ecological" approaches are based on alluvial habitat regionalisation, ecosystems, and communities of plants and animals, i.e., they are based on the actual vegetation structure, especially in the case of alluvial communities (Kř́žžek et al., 2006).

Since anthropogenic activities have fundamentally altered the conditions for the presence of different plant and animal species, as well as the extent of the vegetation cover, however, this method of delineation of the river landscape is very difficult to realise in practice. Such a concept of floodplain (or river landscape) can only be applied to natural and naturerelated segments of watercourses or areas where there is only minimum intensive farming (Chuman, 2008). From a practical viewpoint, the above-mentioned procedure has only limited applications in Czech conditions, as documented by the experimental delineation of the river landscape in the Košátecký Stream basin, based on data from the mapping of the NATURA 2000 habitats at the 1:10,000 scale (Nature Conservation Agency of the Czech Republic (NCA CR)). To define forest covers, we referred to the forest typological maps of the Forest Management Institute (FMI), available in the same spatial resolution. An overview of all the approaches used to define the river landscape in the selected study areas is shown in Table 2.

We applied these methodological approaches on eight independent watercourse reaches (see Tab. 3) in order to analyse the basic variables influencing the river landscape areas in the given conditions, to compare the achieved results, and to evaluate the potential of individual approaches and their applicability. While the pedological and hydrological approaches were applied to both studied watercourses throughout their length (from source area to mouth), the other methodological procedures (i.e. the topographical and the geobotanical) were applied only in three selected stream segments, with parameters typical for the upland, piedmont, and lowland zones (production, transfer and deposition areas, respectively).

\section{Results}

\subsection{River landscape delineation based on the pedological and hydrological approaches}

The width of the river landscape of the Borovsky Stream in the Bohemian-Moravian Highlands varies significantly in its longitudinal profile from the headwater area to its mouth, with noticeable differences in the transfer and deposition zones. Both approaches were used to document the width variability of the river landscape and define the

\begin{tabular}{lll}
\hline Methodological approach & Data source (provider) & Data scale \\
\hline Pedological (P) & Complex Soil Survey (BSEU) & $1: 5,000$ \\
& Forest Typological Maps (FMI) & $1: 10,000$ \\
Hydrological (H) & Maps of inundation areas (TGM WRI) & $1: 10,000$ \\
Topographical* (T) & DEM, $5^{\text {th }}$ generation (COSMC) & mean altitude error \\
& & $0.18 / 0.30 \mathrm{~m}^{* *}$ \\
Geobotanical (G) & NATURA 2000 habitat mapping (NCA CR) & $1: 10,000$ \\
& Forest Typological Maps (FMI) & \\
\hline
\end{tabular}

Tab. 2: Approaches and data sources used in river landscape delineation in the study areas (Notes: *This approach is based on application of the "Fluvial Corridor" Tool [Alber and Piégay, 2011]; ** In forest covered terrain) Source: authors' conceptualisation

\begin{tabular}{lccc}
\hline Stream/segment localisation & $\begin{array}{c}\text { Stream/segment length } \\
\mathbf{( k m )}\end{array}$ & Stream kilometrage & $\begin{array}{c}\text { Approach used to } \\
\text { delineation }\end{array}$ \\
\hline Borovský Stream/entire stream & 17.88 & $0.00-16.61$ & $\mathrm{P}, \mathrm{H}$ \\
Košátecký Stream/entire stream & 24.21 & $0.00-23.56$ & \\
Borovský Stream/upland & 1.14 & $12.71-13.85$ & $\mathrm{P}, \mathrm{H}, \mathrm{T}, \mathrm{B}$ \\
Borovský Stream/piedmont & 2.09 & $5.06-7.15$ & \\
Borovský Stream/lowland & 1.54 & $0.22-1.76$ & \\
Košátecký Stream/upland & 4.73 & $18.73-23.46$ & $\mathrm{P}, \mathrm{H}, \mathrm{T}, \mathrm{B}$ \\
Košátecký Stream/piedmont & 3.99 & $13.79-17.78$ & \\
Košátecký Stream/lowland & 5.06 & $7.84-12.90$ & \\
\hline
\end{tabular}

Tab. 3: Selected characteristics of the studied stream segments and approaches used for river or stream landscape delineation (Notes: $P=$ pedological; $H=$ hydrological; $T=$ topographical; and $B=$ geobotanical approach) Source: authors' elaboration 
river ecosystem along the entire length of the Borovský Stream (see Fig. 2). The values in this figure showed the sudden increase of the average width of the hydrologicallydefined river landscape in the river segment between $\mathrm{km} 11.00$ and 10.00 , which acts as the natural boundary between the upland zone of the streambed with lower width variability, and the lowland zone with much more significant fluctuations in the fluvial ecosystem. The main reason for this increase in the width of the river landscape is the presence of lateral valleys with several tributaries to the Borovský Stream (e.g. the Jitkovský Stream and a nameless tributary at $\mathrm{km} 9.92$ of the river). The transfer zone in terms of sediment regime was relatively steady; in this part, erosion and accumulation stream segments often alternated, and they were usually only a few tens of metres long. This part of the streambed was typical for a deep valley with relatively steep slopes that limit the extent of the river landscape with an average width of 60 and $120 \mathrm{~m}$ in diameter. In the lowland zone, the span of the hydrologically-delineated river landscape increased due to the naturally increased aggradation activity of the stream, thus creating a flat floodplain (in some cases exceeding $200 \mathrm{~m}$ in width). The area of the hydrologicallyconceived river landscape on the lowland segments is increased by the presence of valleys on the other side, often nameless drained streams. At the very end of the Borovský Stream valley, in the cadastral area of the village of Stríibrné Hory, the area affected by the watercourse is artificially limited due to a road embankment dividing the valley floor into two parts.

According to the pedological approach, the average width of the river landscape along the Borovský Stream had a somewhat lower variance than that provided by the hydrological concept (standard deviation $=40.426$ metres; pedological approach: s.d. $=45.586$ metres, hydrological concept). The pedological approach, however, had the advantage of providing data on the dynamic interchange of erosion and aggradation segments of the streambed. The upper boundary of the pedologically-defined river landscape area (i.e. $\mathrm{km} \mathrm{14.30)}$ included segments with a significant spatial extent of the fluvial ecosystem in the longitudinal profile, mostly due to the lithological and morphological features of the valley floor. In particular, the stream segment between $\mathrm{km} 13.50$ and 12.50 , in a widely open valley on the cadastral territory of the village of Havličkova Borová, developed a significant ecosystem (width of about $100 \mathrm{~m}$ ) in the river landscape. Another large segment of the river landscape was located approximately between $\mathrm{km} 7.25$ and 5.00. The main reason for the relatively sudden increase of the river landscape area in this location was the presence of a large number of tributaries (Jitkovský and Modlíkovský Stream, Bělá Stream, and also several unnamed, especially left-side, tributaries), contributing significantly to the transport and aggradation of sediments from the upland part. The last segment, which was an above-average developed area of the river landscape, was located near the mouth of the stream, in the cadastral territory of the village of Stříbrné Hory (km 1.40 to 0.50). Further, the Sázava River as a recipient of the Borovský Stream, had a significant impact, as the river can deposit entrained material and to some extent influence the spatial extent of the river ecosystem during high discharges in this location.

Significant anthropogenic impacts on the hydrographic network of the Košátecký Stream basin are a direct cause of the present form and spatial extent of the stream ecosystem and of other factors. These factors become apparent when comparing the genetically conceived concept of the river landscape (i.e., the pedological approach) with the concept derived purely from the topographical features of a relief and its relative elevation above the riverbed level (the hydrological approach, see Fig. 3). The hydrologically defined river landscape currently has its upper limit on the cadastral territory of the municipality of Kropáčova Vrutice (km 20.12) at a site with abundant springs only a few hundred metres behind the actual beginning of the permanent watercourse. In terms of the variability of the river landscape width, the difference in variability was not very noticeable; the standard width deviation in the pedologically-conceived river landscape was 262.80, and in the hydrological approach, it was 258.69. A high degree of variability was afforded by the existence of two segments, where the defined area reached significantly larger widths than at other sites. The stream segment between $\mathrm{km} 18.50$ and 16.50 is a hydrologicallydefined area due to the morphological features of the valley floor, which is much flatter, thus providing an intensive accumulation of sediment loads transported to the deep valley from the headwater area over a distance of more than $20 \mathrm{~km}$. The second and much more extensive area of river landscape is the segment located approximately between $\mathrm{km} 8.20$ and 6.00. This area, however, represents a specific case because the stream flows across the extensive lowlands formed by the Holocene sediments of the Elbe River. Principally, these are probably not the fluvial sediments of the Košátecký Stream. The lateral spatial extent of the pedologically-conceived river landscape was based on the interpolated boundary of a 100-year flood area, which may include the recent sediment storage area of the Košátecký Stream, which is active during major floods.

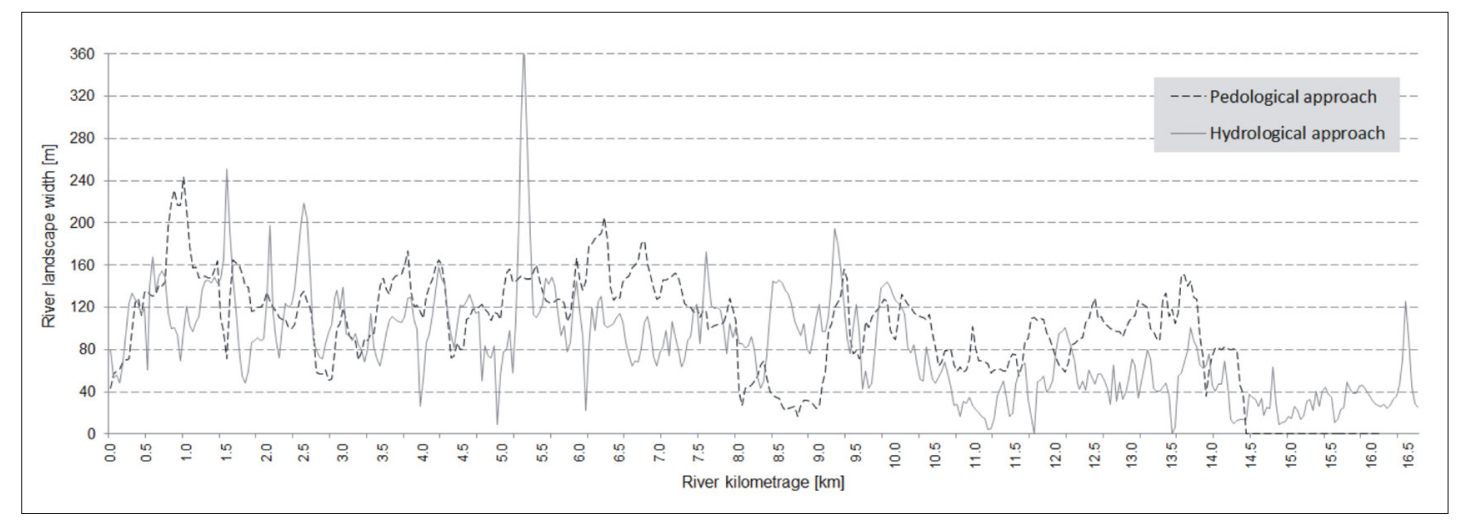

Fig. 2: The width of the river landscape according to the hydrological and pedological approaches delineated along the Borovsky Stream, averaged in 50 m reaches. Source: authors' elaboration based on TGM WRI (2019) data 


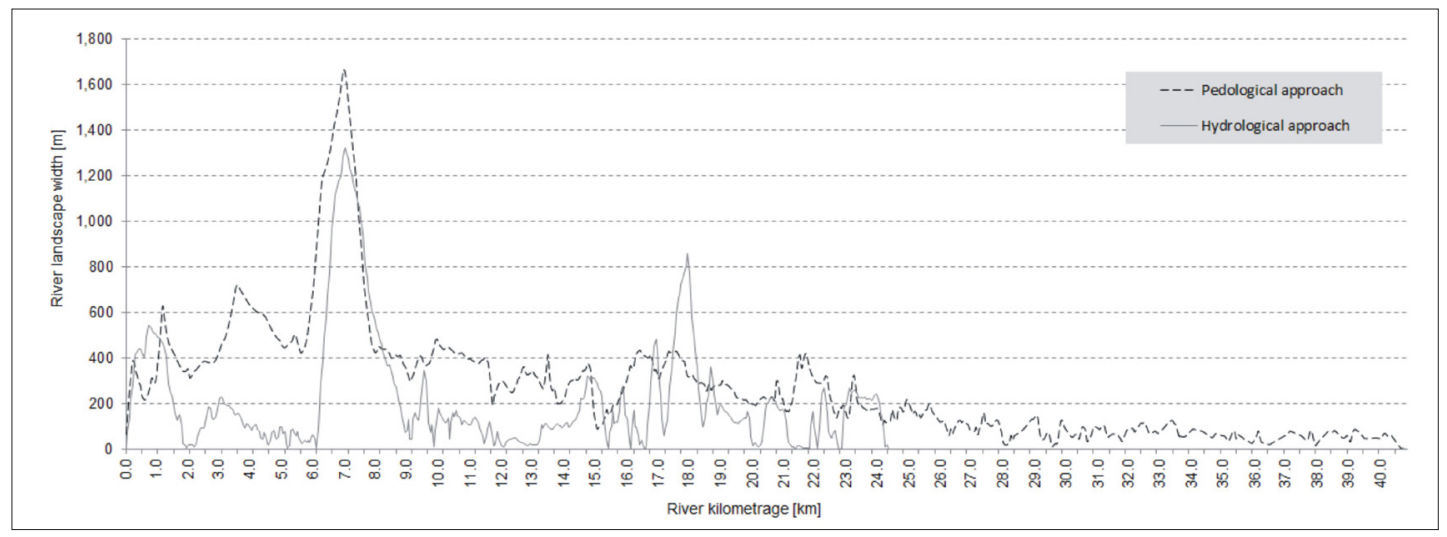

Fig. 3: The width of the river landscape according to the hydrological and pedological approaches delineated along the Košátecký Stream, averaged in 50 m reaches. Source: authors' elaboration based on TGM WRI (2019) data

In the hydrologically-defined area, a small increase in the segment near the mouth of the stream into the Elbe River was influenced by the floodplain area of the Elbe River. The total area of the studied river landscape in the given segment (roughly between $\mathrm{km} 2.00$ and 0.00 ) was degraded, however, due to the presence of industrial anthropogenic forms of relief that affected the local topography. In comparison, the definition of river landscape based on soil properties only revealed a linear dependence in the form of a segment consisting of the Holocene fluvial sediments from the Elbe River; nonetheless, there was a continual extension of the river landscape area in the flow direction. This trend revealed the influence of local topographical conditions on the ongoing erosion-aggradation processes, and the character of the spatial distribution of accumulation areas along the stream.

\subsection{Other approaches used to define the river landscape along small watercourses}

For a more detailed assessment of the gradient of changes in the spatial extent of the river landscapes, we applied the above-mentioned methodological approaches on the representative segments of the Borovský and the Košátecký Stream. The selected stream segments were characterised by features typical for the upland, piedmont and lowland parts of a basin (e.g. hydrological or flood regime, erosionaccumulation capacity of the riverbed, or other natural conditions of the surrounding landscape). As shown in Figure 4, the gradient of changes in the longitudinal profile was not significant for the Borovský Stream ecosystem in the Bohemian-Moravian Highlands. This gradient was the effect of a permanent geological structure influencing the extent of the river landscape and did not allow a continuous increase from the upland to the mouth of the stream. Generally, the stream morphology reacted to these types of influences by extending its fluvial environment (part of the valley floor with active or passive contact with the stream) in the middle (piedmont) part of the river basin, where the erosion and aggradation segments often changed dynamically. In the lowland part, however, the stream tended to partially downsize. An important reason was the junction of several tributaries of the Borovský Stream in the transport zone of the catchment. In addition to the above-mentioned natural causes, anthropogenic activities in the landscape, concentrated mainly in the headwater part of the basin, also may have produced an increase in the spatial extent of the middle part of the river landscape (the stream segment located near the village of Macourov, see Fig. 5).

In the case of the Košátecký Stream, it is evident that the past natural geomorphic evolution of the watercourse made it possible to form a river (stream) landscape which was characterised by continuous expansion from the headwater area to the lowland part. Nowadays, the remains of this stream landscape can be identified using soil data (pedological approach). However, since the river basin is located in an intensively agriculturally exploited area, there have been significant human interventions into the local stream

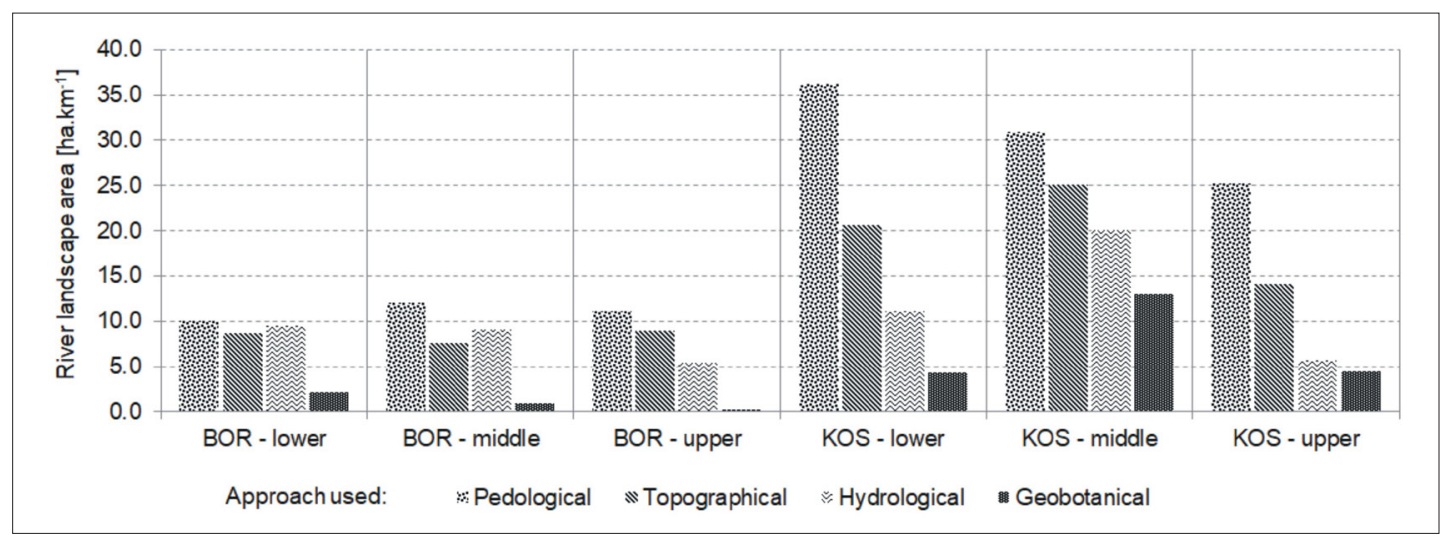

Fig. 4. The relative spatial extent of the river landscapes (for a segment of $1 \mathrm{~km}$ ), delineated according to the selected approaches for three stream segments (upper, middle and lower segments) of the Borovsky Stream (BOR) and Košátecký Stream (KOS). Source: authors' elaboration based on data from the following authorities: Research Institute for Soil and Water Conservation (RISWC), Czech Geological Survey (CGS), Czech office for surveying, mapping and cadastre (COSMC), T. G. Masaryk Water Research Institute (TGM WRI), and Nature Conservation Agency of the Czech Republic (NCA CR) 
landscape, which were most significant in the upper and lower parts of the river basin. For this reason, now we can observe that the middle part of the stream (piedmont) and surrounding landscape is characterised by the relatively best preserved natural values. This is also reflected in the stream landscape area, which reaches its largest dimensions here according to the hydrological, topographical and geobotanical approach (Fig. 4), which responds more flexibly to changes in the landscape caused by current human activities.

The ecosystem of the Košátecký Stream riverbed was characterised by a gradual increase of the spatial extent from the headwater area to the middle part of the catchment. Conversely, the extent of the fluvial ecosystem in the lower stream was characterised by a slight decrease. This finding was observed in most of the methodological approaches applied, apart from the pedological concept. Regarding the change in the spatial extent of the river landscape, the highest increase was seen in the pedological delineation, whereby a defined area of over 180 ha occurred in the lower stream segment (around the village of Byšice, see Fig. 6). This result was very different from those obtained in the other approaches used. The main reason for this might be the occurrence of a deep and narrow valley bottom in the upper and middle part of the catchment, bounded by the slope foot positions. Further, the maximal limits of the river landscape do not provide much room for the uncertainty caused by the field mapping of the soil parameters at this site.

\section{Discussion and conclusions}

The outputs of the study, carried out at two small catchments in the Czech Republic, each with their own unique natural conditions and anthropogenic pressures, point to the validity of the aforementioned fact across the whole range of factors shaping the river (or stream) landscape. Differences between the tested approaches are apparent both in the case of the natural ("close to nature") status of the river network and adjacent landscape, as well as in basins influenced by human activity. By applying several approaches to define the landscape phenomenon at model sites, the results showed the relation of the extent of the area on its specific location within the stream catchment. The extent of the scattering of values increased from the headwater areas (respective sites near the upper limit of the river landscape) to the lower parts of the catchments. There

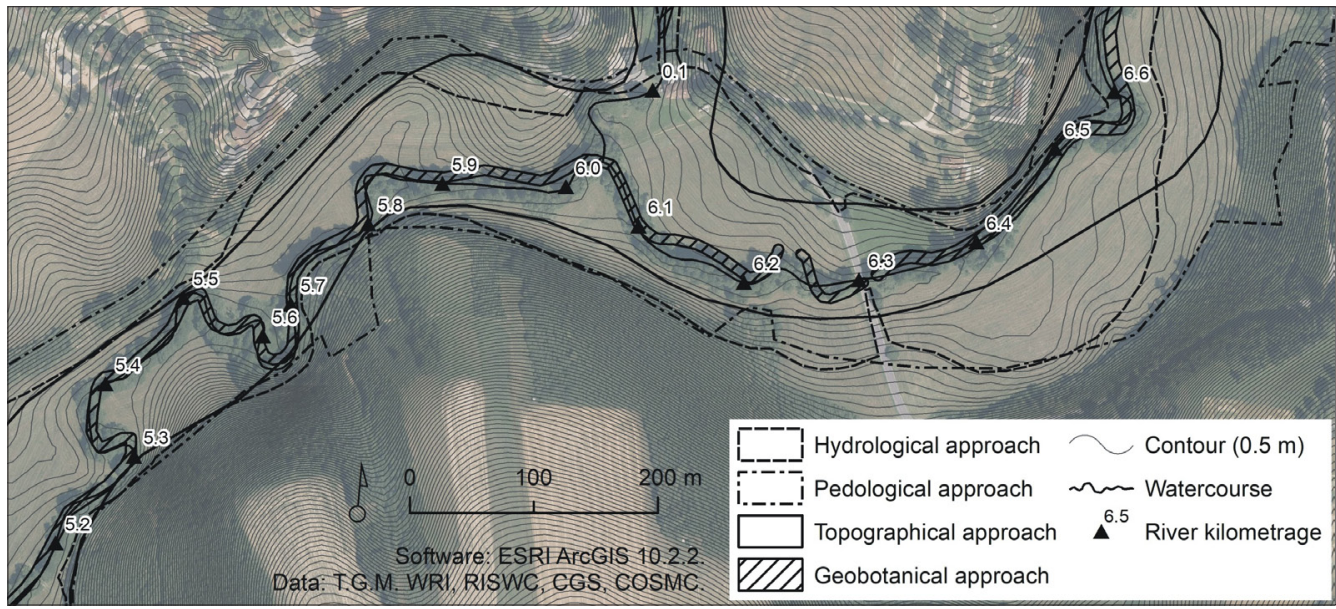

Fig. 5: The approaches used in river landscape delineation applied to a selected segment of the Borousky Stream (middle part of the catchment near the village of Macourov)

Source: authors' elaboration

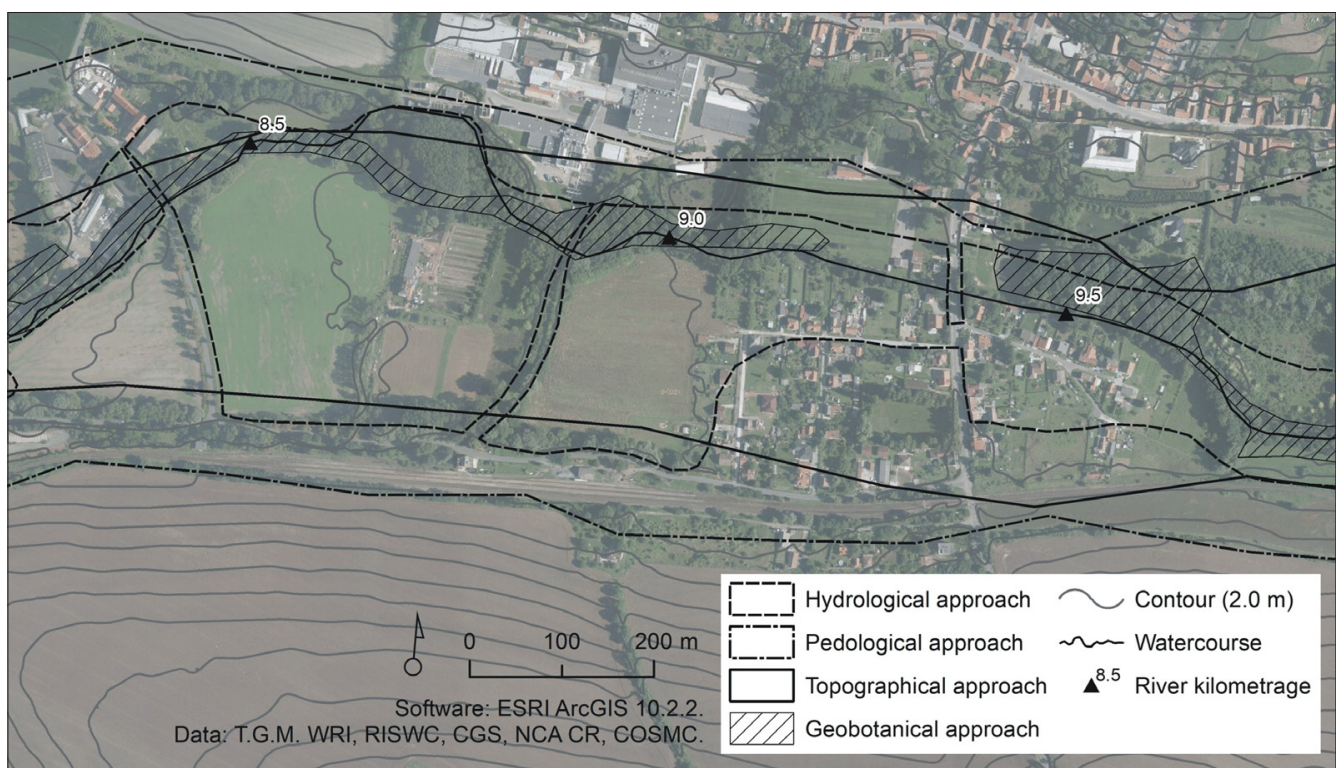

Fig. 6: The approaches used in river landscape delineation applied on a selected segment of the Košátecký Stream (lower part of the catchment near Byšice village)

Source: authors' elaboration 
were significantly greater differences between individual concepts identified at lower segments of the watercourses, flowing through large flats with huge sedimentary layers, and usually formed by the recipient's activities. For example, the difference between the pedological and hydrological approaches in relation to the lower part of the Košátecký Stream amounted to 25 hectares of land per $1 \mathrm{~km}$ of the riverbed. Significant differences could be observed, especially between the approaches that considered the relief genesis (i.e. the pedological concept and partially the geobotanical concept), and the concepts based only on the morphometric parameters of the terrain and its relative elevation above the riverbed level (i.e. the hydrological and the topographical concepts).

Although the results of the hydrological and topographical approaches for the selected stream segments were in some cases very different, there were no hypothetical differences, since both approaches are based on similar principles of field delimitation. In this study, however, the topographical approach was experimentally implemented using the "FluvialCorridor" extension ("Valley Bottom" tool), which was designed for the automated delineation of fluvial areas along watercourses. This approach produced accurate results only at sites with a rugged topography and a clearly definable spatial extent of the valley bottom. The probability of error increases in flat terrain and such a situation occurred in the Košátecký Stream basin. Consequently, significant differences could occur between the topographical and hydrological concepts in all the studied stream segments. Since the authors of the tool (Roux et al., 2015) are aware of the deficiencies, the algorithm for automated delimitation is being further developed and refined. The tool is gradually expanding and being applied to various model territories (e.g. Demarchi et al., 2016). The authors of other software that can be used to delineate river landscape, e.g., the "Valley Bottom Extraction Tool" (Gilbert et al., 2016), are trying to eliminate the potential errors connected to river landscape delineation.
In this study, the river landscape was experimentally delineated following the geobotanical approach, but its application achieved significantly undervalued results compared to the other methods. The reason is that both locations studied represent a cultural landscape where the structure and size of each habitat type is strongly influenced by anthropogenic activities. The extent of discrete fragments of habitats bound to a fluvial environment is limited by the use of the surrounding landscape. For this reason, in the current Central European landscape, the geobotanical concept may be applied only to legally protected areas. An alternative to the geobotanical procedure to determine the extent of the inundation areas may be the method based on the analysis of the normalised differential vegetation index (NDVI), proposed by Powell et al. (2014). This method is applicable only to specific environments, however, optimally after a flood episode, within the inundation areas.

All the methods used for the delineation of river landscapes and their positives and negatives related to the application to small streams, are summarised in the SWOT analysis shown in Table 4, identifying strengths, weaknesses, opportunities, and threats related to each approach. The results of our study also showed that the largest extent in all the selected stream segments was the river (stream) landscape defined according to its soil characteristics. Considerable overestimation compared to other approaches was apparent in intensively cultivated landscapes, i.e. the headwater area of the Borovský Stream catchment and the lower part of the Košátecký Stream catchment (see Figs. 2 and 3). These areas are typical in flat terrain where relatively large inundations exceeding the area of the current floodplain may have occurred in the past; thus, the data may correspond to the real area of the hydromorphic soils. With regard to the definition of river landscapes, the area thus defined must necessarily include sites which do not meet this characteristic because they do not have permanent or at least periodic contact with the current riverbed. Lowland areas with flat terrain

\begin{tabular}{|c|c|c|c|c|}
\hline Approach used & Strengths & Weaknesses & Opportunities & Threats \\
\hline $\mathrm{P}$ & $\begin{array}{l}\text { Higher resolution of } \\
\text { analogue data, availability } \\
\text { of underlying data }\end{array}$ & $\begin{array}{l}\text { Demands on processing } \\
\text { of analogue data, lower } \\
\text { accuracy of digital data, } \\
\text { the need to use multiple } \\
\text { data sources (agricultural/ } \\
\text { forest land) }\end{array}$ & $\begin{array}{l}\text { Possibility of further data } \\
\text { refinement by field survey } \\
\text { (soil probes) }\end{array}$ & $\begin{array}{l}\text { Use of inaccurate data in } \\
\text { digital form }\end{array}$ \\
\hline $\mathrm{H}$ & Higher data resolution & $\begin{array}{l}\text { Unavailability of data for } \\
\text { small streams, demands } \\
\text { on the input data for } \\
\text { modelling, defining } \\
\text { inaccuracy in flat terrain }\end{array}$ & $\begin{array}{l}\text { Opportunity to add data } \\
\text { based on hydrological } \\
\text { modelling even for small } \\
\text { streams }\end{array}$ & Time limited data validity \\
\hline $\mathrm{T}$ & $\begin{array}{l}\text { Availability of analogue as } \\
\text { well as digital underlying } \\
\text { materials, the possibility of } \\
\text { rapid processing, very high } \\
\text { accuracy }\end{array}$ & $\begin{array}{l}\text { Inaccurate delineation in } \\
\text { flat terrain }\end{array}$ & $\begin{array}{l}\text { Ability to use very } \\
\text { accurate data (LIDAR), the } \\
\text { possibility of automation }\end{array}$ & $\begin{array}{l}\text { Misinterpretation of data, } \\
\text { temporary data validity }\end{array}$ \\
\hline B & $\begin{array}{l}\text { Higher resolution of } \\
\text { underlying materials in } \\
\text { analogue and digital form }\end{array}$ & $\begin{array}{l}\text { Difficult accessibility of } \\
\text { data, unavailability for } \\
\text { the whole territory of the } \\
\text { Czech Republic }\end{array}$ & $\begin{array}{l}\text { Possibility to refine/create } \\
\text { data by field survey }\end{array}$ & $\begin{array}{l}\text { Misinterpretation of data } \\
\text { during field survey, time } \\
\text { limited data validity }\end{array}$ \\
\hline
\end{tabular}

Tab. 4: SWOT analysis of individual approaches used to delineate the fluvial ecosystem in terms of their efficiency and complexity (Note: $P=$ Pedological; $H=H y d r o l o g i c a l ; ~ T=$ Topographical; $B=$ Geobotanical approach. The grey colour range of each column indicates the weight of the factors in the analysis the more intense the color, the greater the weight of the identified factors])

Source: authors' elaboration 
and minimal elevation above the riverbed edge can be the most problematic in terms of river or stream landscape delineation.

In areas with more rugged relief and in an urban environment, the most accurate approach to define a river landscape is the method based on topographical data, which was confirmed in the two analysed areas and corresponds also to the conclusions of other authors: e.g. Deshpande 2013; Notebaert and Piégay, 2013. Moreover, our study confirms the fact that this is especially due to the accuracy of the data and its availability for small watercourses, which remains the key factor affecting the accurate definition of the river landscape.

The results show that the various concepts of a fluvial ecosystem lining a small watercourse can vary considerably in terms of its extension and spatial distribution within the basin. Traditionally, among the most commonly used approaches is the hydrogeomorphic floodplain delineation method, which is a GIS-based approach linking a simplified inundation method with the geomorphic properties of the stream network and hydrologic characteristics of a flood event (e.g. Nardi et al., 2006). The floodplain or river landscape definition on the basis of the digital elevation model has generally received a lot of attention (i.e., Noman et al., 2003; Charrier and Li, 2012; Deshpande, 2013), as it was a method based on relatively easily accessible data and, at the same time, sufficient accuracy of the outputs. Moreover, the increasing global availability of high-accuracy DEMs or DTMs (Digital Terrain Models) derived from earth observation technology (e.g., satellite, aerial or drones), offers new opportunities for advancing large-scale floodplain mapping (Nardi et al., 2018). Current and relatively accurate information on the area of great river floodplains can be obtained on the basis of elevation data processed by a fast geo-spatial tool for floodplain mapping (GFPLAIN $250 \mathrm{~m}$, see Nardi et al., 2019), but this tool is only suitable for large river systems.

In order to determine the extent of a river (stream) landscape along small watercourses, however, it is necessary to use other data sources, especially soil cover data, which will increase the accuracy of the delimitation. The main contribution of this article lies in a comparison of four different approaches to delimiting a river (stream) landscape in terms of its applicability to small watercourses, whose ecosystems are a very important part of the landscape structure and perform a wide range of ecosystem functions and services.

GIS modeling techniques, based on the existence of an accurate digital terrain model, are increasingly being used to define river landscapes. Considerable attention is paid to this method because it is relatively easy to define, without the need for any field surveys. In general, using the correct and sufficiently comprehensive GIS tools (preferably fully integrated 2-D hydrologic and hydraulic modeling) can achieve relatively accurate results by this procedure, but it is still recommended to verify the validity of the resulting data by field surveys. The other delineation methods presented in this article are used much less frequently, mainly because of their time-consuming requirements; however, especially in the case of the pedological approach, it is a very precise method by which it is possible to identify sites clearly recently affected by a river.

Although the issues discussed in the article were applied to small catchment areas in the Czech Republic and the data used were "country-unique", it can be assumed that the conclusions regarding the applicability of different approaches to delineating the river landscapes and their accuracy can be used at a global scale, i.e., at the international river basin or hydrogeological region levels. It can be stated that most of the knowledge gained by the SWOT analysis is generally valid outside the Czech Republic as well, and that the conclusions can be applied, especially in practice, for the purpose of delineating the river landscape as a territory subject to the protection of natural value in terms of conservation.

\section{Acknowledgements}

This study was supported by the Ministry of Education, Youth, and Sports of the Czech Republic in the National Sustainability Program I (NPU I), grant number LO1415; and also by the projects: "Small watercourses and riparian ecosystem management to mitigate the impacts of environmental change (SMART2Envi)", grant number LTC18069, and "LAND4FLOOD: Natural Flood Retention on Private Land", grant number LTC18025.

\section{References:}

ALBER, A., PIÉGAY, H. (2011): Spatial aggregation procedure for characterizing physical structures of fluvial networks: applications to the Rhône basin. Geomorphology, 125(3): 343-360.

ALTDORF, D., EPTING, J., KRUK, J. V. D., DIETRICH, P., HUGGENBERGER, P. (2013): Delineation of fluvial sediment architecture of subalpine riverine systems using noninvasive hydrogeophysical methods. Environmental earth sciences, 69(2): 633-644.

AMOROS, C., ROUX, A. L. (1988): Interactions between water bodies within the floodplains of large rivers: function and development of connectivity. In: Schreiber, K. F. [ed.]: Connectivity in landscape ecology (pp. 125-130). Muenster, Muensterische Geographische Arbeit.

BLAUHUT,V.,STAHL, K., STAGGE,J. H., TALLAKSEN,L. M., STEFANO, L. D., VOGT, J. (2016): Estimating drought risk across Europe from reported drought impacts, drought indices, and vulnerability factors. Hydrology and Earth System Sciences, 20(7): 2779-2800.

CARBONNEAU, P., FONSTAD, M. A., MARCUS, W. A., DUGDALE, S. J. (2012): Making riverscapes real. Geomorphology, 137: 74-86.

CLUBB, F. J., MUDD, S. M., MILODOWSKI, D. T., VALTERS, D. A., SLATER, L. J., HURST, M. D., LIMAYE, A. B. (2017): Geomorphometric delineation of floodplains and terraces from objectively defined topographic thresholds. Earth Surface Dynamics, 5(3): 369-385.

COLLIN, P.H. (1988): Dictionary of Ecology and the Environment. Peter Collin Publishing, Teddington Park.

DEMARCHI, L., BIZZI, S., PIÉGAY, H. (2016): Hierarchical Object-Based Mapping of Riverscape Units and inStream Mesohabitats Using LiDAR and VHR Imagery. Remote Sensing, 8(2): 97.

DESHPANDE, S. S. (2013): Improved Floodplain Delineation Method Using High-Density LiDAR Data. ComputerAided Civil and Infrastructure Engineering, 28: 68-79.

DÉCAMPS, H. A., FORTUNE, M., GAZELLE, F., PAUTOU, G. (1988): Historical influence of man on the riparian dynamics of a fluvial landscape. Landscape Ecology, 1: 163-173. 
DUFOUR, S., RODRÍGUEZ-GONZÁLES, P. M., LASLIER, M. (2019): Tracing the scientific trajectory of riparian vegetation studies: Main topics, approaches and needs in a globally changing world. Science of the Total Environment, 653: 1168-1185.

EEA (2016): Floodplain management: reducing flood risks and restoring healthy ecosystems. European Environment Agency. Available at: https://www.eea.europa.eu/ highlights/floodplain-management-reducing-flood-risks

FAO (1988): Soil map of the world. Revised legend. World Soil Resources Report, No. 60. Rome, FAO-UNESCOISRIC.

FAUSCH， K. D., TORGERSEN， C. E., BAXTER, C. V., LI, H. W. (2002): Landscapes to riverscapes: bridging the gap between research and conservation of stream fishes. BioScience, 52(6): 483-498.

GILBERT, J. T., MACFARLANE, W. W., WHEATON, J. M. (2016): The Valley Bottom Extraction Tool (V-BET): A GIS tool for delineating valley bottoms across entire drainage networks. Computers \& Geosciences, 97: 1-14.

GURNELL, A. M., PETTS, G. E. (2002): Island-dominated landscapes of large floodplain rivers: A European perspective. Freshwater Biology, 47: 581-600.

HEIN, T., SCHWARZ, U., HABERSACK, H., NICHERSU, I., PREINER, S., WILLBY, N., WEIGELHOFER, G. (2016): Current status and restoration options for floodplains along the Danube River. Science of the Total Environment, 543: 778-790.

HUGGETT, R. J. (2003): Fundamentals of geomorphology. London, Routledge.

CHARRIER, R., LI, Y. (2012): Assessing resolution and source effects of digital elevation models on automated floodplain delineation: a case study from the Camp Creek Watershed, Missouri. Applied Geography, 34: 38-46.

CHUMAN, T. (2008): Vymezení nivy pomocí pedologických a biogeografických podkladů na př́kladu povodí Opavy. In: Langhammer, J. [ed.]: Údolní niva jako prostor ovlivňující průběh a následky povodní (pp. 178-184). Praha, KFGG PřF UK.

ILHARDT, B. L., VERRY, E. S., PALIK, B. J. (2000): Defining Riparian Areas. In: Wagner, R. G., Hagan, J. M. [ed.]: Forestry and the riparian zone (pp. 7-14). Conference Proceedings. University of Maine.

JUNK, W. J., WELCOMME, R. L. (1989): Management of floodplains. In: Patten, B., C. [ed.]: Wetlands and shallow continental water bodies. Hague, SPB Academic Publishing

KATSUYAMA， M. N. OHTE， N.，KABEYA， N. (2005): Effects of bedrock permeability on hillslope and riparian groundwater dynamics in a weathered granite catchment, Water Resources Research, 41(1): W01010

KILIANOVÁ, H., PECHANEC, V., BRUS, J., KIRCHNER, K., MACHAR, I. (2017): Analysis of the development of land use in the Morava River floodplain, with special emphasis on the landscape matrix. Moravian Geographical Reports, 25(1): 46-59.

KREIBICH, H., BLAUHUT, V., AERTS, J. C., BOUWER, L. M., VAN LANEN, H. A., ... \& VAN LOON, A. F. (2019): How to improve attribution of changes in drought and flood impacts. Hydrological sciences journal, 64(1): 1-18.
KREJČÍ, L. (2012): Strategie adaptačních opatření pro POP Moravy. Část A - Říční nivy. Olomouc, Koalice pro řeky.

KŘǏŽEK, M., HARTVICH, F., CHUMAN, T., ŠEFRNA, L., ŠOBR, M., ZÁDOROVÁ, T. (2006): Floodplain and its delimitation. Geografie, 111(3): 260-273.

LEOPOLD, L. B., MARCHANT, M. O. (1968): On the Quantitative Inventory of the Riverscape. Water Resources Research, 4(4): 709-717.

LEWIN, J., MANTON, M. M. M. (1975): Welsh floodplain studies: The nature of floodplain geometry. Journal of Hydrology, 25(1-2): 37-50.

LINDSAY, J. B. (2003): A physically based model for calculating contributing area on hillslopes and along valley bottoms, Water Resources Research, 39(12): 1332.

MALANSON, G. P. (1993): Riparian Landscapes. Cambridge Studies in Ecology. Cambridge University Press, Cambridge.

MCGLYNN, B. L., SEIBERT, J. (2003): Distributed assessment of contributing area and riparian buffering along stream networks, Water Resources Research, 39(4): 1082.

NANSON, G. C., CROKE, J. C. (1992): A genetic classification of floodplains. In: Brakenridge, G. R., Hagedorn, J. [eds.]: Floodplain Evolution. Geomorphology, 4: 459-486.

NARDI, F., VIVONI, E. R., GRIMALDI, S. (2006): Investigating a floodplain scaling relation using a hydrogeomorphic delineation method. Water Resources Research, 42: W09409.

NARDI, F., BISCARINI, C., FRANCESCO, S. D., MANCIOLA, P., UBERTINI, L. (2013): Comparing a large-scale DEM-based floodplain delineation algorithm with standard flood maps: the Tiber River basin case study. Irrigation and Drainage, 62(2): 11-19.

NARDI, F., MORRISON, R. R., ANNIS, A., GRANTHAM, T.E. (2018): Hydrologic scaling for hydrogeomorphic floodplain mapping: Insights into human-induced floodplain disconnectivity. River Research and Applications, 34(7): 675-685.

NARDI, F., ANNIS, A., DI BALDASSARRE, G., VIVONI, E. R., GRIMALDI, S. (2019). GFPLAIN250m, a global high-resolution dataset of Earth's floodplains. Scientific data, 6: 180309 .

NILSSON, C., REIDY, C. A., DYNESIUS, M., REVENGA, C. (2005): Fragmentation and Flow Regulation of the World's Large River Systems. Science, 308 (5720): 405-408.

NOMAN, N. S., NELSON, E. J., ZUNDEL, A. K. (2003): Improved process for floodplain delineation from digital terrain models. Journal of water resources planning and management, 129 (5): 427-436.

NOTEBAERT, B., PIÉGAY, H. (2013): Multi-scale factors controlling the pattern of floodplain width at a network scale: The case of the Rhône basin, France. Geomorphology, 200: 155-171.

POWEL， S. J., JAKEMAN，A., CROKE，B. (2014): Can NDVI response indicate the effective flood extent in macrophyte dominated floodplain wetlands? Ecological Indicators, 45: 486-493.

RATHJENS, H., BIEGER, K., CHAUBEY, I., ARNOLD, J. G., ALLEN, P. M., SRINIVASAN， R., BOSCH， D. D., VOLK, M. (2016): Delineating floodplain and upland areas for hydrologic models: a comparison of methods. Hydrological Processes, 30: 4367-4383. 
RINALDI, M., WYZGA, B., DUFOUR, S., BERTOLDI, W. GURNELL, A. (2013): River Processes and Implications for Fluvial Ecogeomorphology: A European Perspective. In: Schroder J. F. [ed.]: Treatise in geomorphology 12(4): 37-52.

ROUX, C., ALBER, A., BERTRAND, M., VAUDOR, L., PIÉGAY, H. (2015): "FluvialCorridor": A new ArcGIS toolbox package for multiscale riverscape exploration. Geomorphology, 242: 29-37.

SCHINDLER, S., O’NEILL, F. H., BIRÓ, M., DAMM, C., GASSO, V., KANKA, R., ... \& PUSCH, M. (2016): Multifunctional floodplain management and biodiversity effects: a knowledge synthesis for six European countries. Biodiversity and conservation, 25(7): 1349-1382.

ŠTĚRBA, O. a kol. (2008): Ř́ční krajina a její ekosystémy. Univerzita Palackého v Olomouci, Olomouc.

TGM WRI (2019): Digital Base of Water Management Data [online]. Available at: http://www.dibavod.cz/

TOCKNER, K., MALARD, F., WARD, J. V. (2000): An extension of the flood pulse concept. Hydrological Processes, 14: 2861-2883.

TOCKNER, K., STANFORD, J.A. (2002): Riverine Flood Plains: Present State and Future Trends. Environmental Conservation, 29: 308-330.

VANNOTE, R. L., MINSHALL，G.W, CUMMINS, K. W., SEDELL, J.R., CUSHING, C. E. (1980): The river continuum concept. Canadian journal of fisheries and aquatic sciences, 37(1): 130-137.
WAKPP (2016): Webový archiv Komplexního průzkumu půd. Výzkumný ústav meliorací a ochrany půd [online]. [cit. 31. 5. 2017]. Available at: http://wakpp.vumop.cz/

WARD, R. (1978): Floods: A Geographical Perspective. Macmillan, Press LTD, London.

WARD, J. V. (1998): Riverine landscapes: biodiversity patterns, disturbance regimes, and aquatic conservation. Biological conservation, 83(3): 269-278.

WARD, J. V., ROBINSON, C. T., TOCKNER, K. (2002): Applicability of ecological theory to riverine ecosystems. Internationale Vereinigung für theoretische und angewandte Limnologie: Verhandlungen, 28(1): 443-450.

WIENS, J. A. (2002): Riverine landscapes: taking landscape ecology into the water. Freshwater biology, 47(4): 501-515.

WILLIAMS, W. A., JENSEN, M. E., WINNE, J. C., REDMOND, R. L. (2000): An automated technique for delineating and characterizing valley-bottom settings. In: Sandhu, S. S. et al. [eds.]: Monitoring Ecological Condition in the Western United States (pp. 105-114). Dordrecht, Springer.

WINTER, T. C. (2001): The Concept of Hydrological Landscapes. Journal of the American Water Resources Association, 37(2): 335-349.

WITNER, D. B. (1966): Soils and Their Role in Planning a Suburban Community. In: Bartelli, L. J. Klingebiel, A. A. Baird, J. V., Heddleson, M. R. [eds.]: Soil Surveys and Land Use Planning (pp. 15-30). Madison, Soil Science Society of America and American Society of Agronomy.

\section{Please cite this article as:}

JAKUBÍNSKÝ, J., HERBER, V., CUDLÍN, P. (2019): A comparison of four approaches to river landscape delineation: The case of small watercourses in the Czech Republic. Moravian Geographical Reports, 27(4): 229-240. Doi: 10.2478/mgr-2019-0018. 